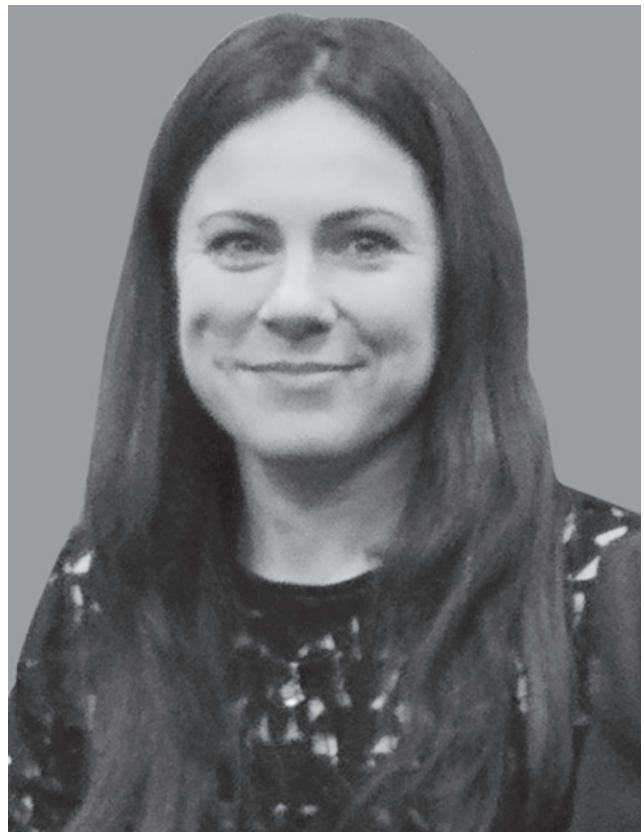

Mykhailovska Olena Vasilievna,

of public and corporate management in Chernihiv Pohytechnic National University, 14035, of public and corporate management in Chernihio Polytechnic National University, 14035, Chernihiv, Shevchenko Str., 95, tel.: (050) 355-02-85, e-mail: m-olena@ukr.net, http://orcid. org/0000-0002-7682-2292

\title{
АКТУАЛЬНІ ПИТАННЯ ГРОМАДСЬКОЇ АКТИВНОСТІ В СИСТЕМІ ПУБЛІЧНОГО УПРАВЛІННЯ
}

Анотація. Схарактеризовано сутність правової держави та громадянського суспільства. З'ясовано, що неурядові організації є елементами громадянського суспільства, що виконують широке коло функцій, серед яких: захист прав людини, боротьба за роззброєння, здійснення дослідницьких та освітніх заходів тощо. Встановлено, що такі організації створюють для громадян умови та можливості щодо безпосередньої участі в налагодженні партнерської співпраці з органами влади й міжнародними організаціями. Виявлені наявні проблеми взаємодії неурядових громадських організацій (НУО) 3 органами державної влади та місцевого самоврядування. Наголошено, що інформація відносно кількості громадян, залучених до складу громадських організацій, та їх клієнтів не відповідає дійсності. Підтверджено наявні позитивні зміни у політиці влади щодо налагодження конструктивного діа- 
логу з неурядовими громадськими організаціями та підкреслено існування певних негативних тенденцій. Встановлено, що громадські організації визначились з механізмами найбільш ефективного впливу на владу, однак рівень пасивності та байдужості населення є вагомою проблемою їх взаємовідносин з владними структурами. На основі результатів соціологічних опитувань засвідчено зростання довіри українців до громадського сектору та незмінно низький рівень їх активності. Схарактеризовано результати опитування щодо наявності інформації про діяльність НУО у студентів, які засвідчують існування проблем у даній сфері, оскільки респонденти не відрізняють громадські організації від інших об'єднань, організацій і структур державного управління. Констатовано, що НУО мають краще інформувати громадськість про наявний професійний та ресурсний потенціал, визначити заходи спільних дій щодо організаційно-правового забезпечення надання якісних послуг тощо.

Ключові слова: неурядові громадські організації, громадськість, публічне управління, взаємодія.

\section{АКТУАЛЬНЫЕ ВОПРОСЫ ОБЩЕСТВЕННОЙ АКТИВНОСТИ В СИСТЕМЕ ПУБЛИЧНОГО УПРАВЛЕНИЯ}

Аннотация. Охарактеризована сущность правового государства и гражданского общества. Выяснено, что неправительственные организации являются элементами гражданского общества, выполняющими широкий круг функций, среди которых: защита прав человека, борьба за разоружение, осуществление исследовательских и образовательных мероприятий и др. Установлено, что такие организации создают для граждан условия и возможности непосредственного участия в налаживании партнерского сотрудничества с органами власти и международными организациями. Обнаружены проблемы взаимодействия неправительственных организаций (НПО) с органами государственной власти и местного самоуправления. Отмечено, что информация относительно количества граждан, привлеченных в состав общественных организаций, и их клиентов не соответствует действительности. Подтверждены положительные изменения в политике власти по формированию конструктивного диалога с неправительственными общественными организациями и подчеркнуто существование определенных негативных тенденций. Установлено, что общественные организации определились с механизмами наиболее эффективного воздействия на власть, однако уровень пассивности и безразличия населения является важной проблемой их взаимоотношений со структурами государственной и местной властей. На основе результатов социологического опроса засвидетельствован рост доверия украинцев к общественному сектору и неизменно низкий уровень их активности. Охарактеризованы результаты опроса о наличии информации о деятельности НПО среди студентов, которые удостоверяют существование проблем в данной сфере. 
Ключевые слова: публичное управление, общественная активность, неправительственные организации.

\section{CURRENT ISSUES OF PUBLIC ACTIVITY IN THE SYSTEM OF PUBLIC GOVERNANCE}

Abstract. The essence of the rule of law and civil society is characterized. It has been found that non-governmental organizations are elements of civil society that perform a wide range of functions, including the protection of human rights, the fight for disarmament, the implementation of research and educational activities, and so on. It is established that such organizations create conditions and opportunities for citizens to directly participate in establishing partnerships with the authorities and international organizations. The existing problems of interaction of non-governmental public organizations (NGOs) with state authorities and local self-government bodies have been identified. It is emphasized that the information regarding the number of citizens involved in public organizations and their clients is not true. The existing positive changes in the government's policy on establishing a constructive dialogue with non-governmental organizations were confirmed and the existence of certain negative trends was emphasized. It has been established that public organizations have determined the mechanisms of the most effective influence on the government, but the level of passivity and indifference of the population is a significant problem in their relationship with government agencies. Based on the results of opinion polls, Ukrainians' confidence in the public sector has grown and their activity has remained consistently low. The results of the survey on the availability of information about the activities of NGOs among students who testify to the existence of problems in this area are characterized, as the respondents do not distinguish public organizations from other associations and organizations and structures of public administration. It was stated that NGOs should better inform the public about the available professional and resource potential, identify joint actions for organizational and legal support for the provision of quality services, and so on.

Keywords: non-governmental public organizations, public, public administration, interaction.

Постановка проблеми. У наш час зв'язок громадянського суспільства 3 державою та вплив на неї базується на принципах демократії. Формування правової держави завжди вимагало від громадян високого рівня культури, усвідомлення не лише своїх прав, а й визнання обов'язків, повага до прав і свобод інших громадян. В умовах забезпечення демократичних змін зазначене набуває особливої актуальності, оскільки громадянське суспільство має приймати активну участь в публічному управлінні

Аналіз останніх досліджень i публікацій. У відкритому доступі мережі Інтернет наявна велика кількість сучасних публікацій, які 
стосуються питань системи публічного управління та процесів розвитку громадянського суспільства. У наукових колах питання громадської активності в системі управління державою знайшли відображення у працях таких вчених, як Г. Ситник, А. Михненко, О. Руденко, Д. Холдар, I. Абрам'юк, О. Крутій, О. Бабінова, Ю. Шайгородський, Р. Войтович, I. Жукова, О. Крутій та ін.

Після проведеного дослідження літературних джерел, можна стверджувати про актуалізацію питання щодо удосконалення механізмів участі громадян у процесі публічного управління. Погляди різних науковців в основному спрямовані на розгляд загальних питань громадської активності, залишаючи поза увагою вагомий вплив громадських організацій на підвищення активності громадян у зазначеній сфері.

Мета статті. Дослідження ролі неурядових громадських організацій у побудові взаємодії між органами влади й громадянським суспільством.

Виклад основного матеріалу. Вихідним із демократичних принципів є принцип народного суверенітету, який проголошує народ єдиним джерелом і верховним носієм влади у суспільстві [1]. Отже, формування правової держави вимагає послідовного втілення в практику державного врядування важливих принципів взаємодії між всіма елементами системи публічного управління.

Становлення громадянського суспільства як історичної реальності розпочалося з зародженням капіталізму. Виникнення громадянського суспільства пов'язується 3 появою громадянина як самостійного, інди- відуального члена суспільства, який усвідомлює себе таким, наділений певним комплексом невідчужуваних прав і свобод і відповідає перед суспільством за всі свої дії.

Опосередкованість соціального буття людини неминуче призводить до появи добровільних асоціацій та громадських угруповань. Неурядові організації (НУО) (англ. non-governmental organizations - NGOs) - локальні, національні чи міжнародні об'єднання людей, діяльність яких здійснюється $з$ ініціативи громадян, а не з санкції чи вказівки уряду і не має на меті отримання прибутку [2]. Неурядові організації $є$ елементами громадянського суспільства, що виконують широке коло функцій (захист прав людини, боротьба за роззброєння, здійснення дослідницьких та освітніх заходів тощо). Вони створюють для громадян умови та можливості щодо безпосередньої участі в розв'язанні проблем власного життя, у прийнятті рішень, у налагодженні партнерської співпраці 3 органами влади й міжнародними організаціями.

В аналітичному звіті “Стан та динаміка розвитку неурядових організацій України" [3] виокремлені наступні проблеми взаємодії НУО з органами влади: 1) достатньо високий рівень скепсису організованої громадськості щодо можливості впливати на органи влади; 2) нестача зрозумілих, чітко інституалізованих каналів інформації про діяльність органів влади i, як результат, майже повна відсутність дієвих важелів впливу на формування місцевої та регіональної політики. НУО, як правило, користуються інформацією від 
“знайомих у коридорах влади”, здійснюють взаємний обмін інформації про рішення та заходи, які плануються владою тощо; 3) існуючі інституції взаємодії влади та громадськості (консультаційно-дорадчі органи) мають занадто формалізований характер і незначний ефект діяльності; 4) частина неурядових організацій намагається через 3МI висвітлювати свою діяльність, висловлювати своє ставлення до дій влади, однак така діяльність має більше рекламний, ніж дієвий характер; 5) формування так званих “кишенькових" НУО при органах влади, які створюються, насамперед, з метою залучення коштів міжнародних донорських організацій для реалізації планів заходів владних структур, формування ілюзії взаємодії 3 організованим громадянським суспільством.

3 усіма наведеними проблемами, які не втрачають актуальності, автор погоджується, але зауважимо наступне - інформація щодо кількості громадян, залучених до складу громадських організацій та клієнтів НУО, не відповідає дійсності, що, у свою чергу, не дає змоги оцінити масштаби існуючих проблем у даній сфері діяльності [4].

Підтверджуючи наявність позитивних кроків влади щодо налагодження конструктивного діалогу із НУО, зазначимо і про те, що на сьогодні науковці та практики виокремлюють низку негативних тенденцій у даному напрямі [3]: нерозуміння корисності такої співпраці 3 боку владних структур; відсутність у них інформації про діяльність НУО; несвідомість суспільства у сфері співпраці з НУО. Відзначимо, що спів- праця між НУО та органами державної влади й місцевого самоврядування $є$ більш результативною, ніж на загальнодержавному рівні.

Громадська організація "Інформаційно-аналітичний центр "Громадський Простір” наводить цікаві дані щодо опитування, проведеного Фондом “Демократичні ініціативи” серед працівників громадських організацій (рисунок).

Отже, можемо констатувати, що громадські організації визначились 3 механізмами найбільш ефективного впливу на владу. Водночас рівень пасивності та байдужості населення $є$ вагомою проблемою взаємовідносин ГО з владними структурами. Також результати соціологічних опитувань засвідчують, що довіра українців до громадського сектору зростає, але рівень активності - незмінний, чітке розуміння функцій таких організацій відсутнє.

Теоретикам та практикам на даний час необхідно виробити єдину систему оцінки якості діяльності НУО, оскільки, беззаперечно, важливого значення зазначене набуває у процесі формування ефективної взаємодії в системі публічного управління.

Безперечно в Україні наявна велика кількість НУО, які ефективно працюють у певних сферах, але несвідоме ставлення громадян до таких організацій не сприяє поширенню їх діяльності. У таблиці наведені результати опитування, яке було проведено на базі факультету менеджменту, харчових технологій та торгівлі Чернігівського національного технологічного університету. 
За допомогою яких механізмів громадські організації можуть найбільш ефективно впливати на владу? (згадок)

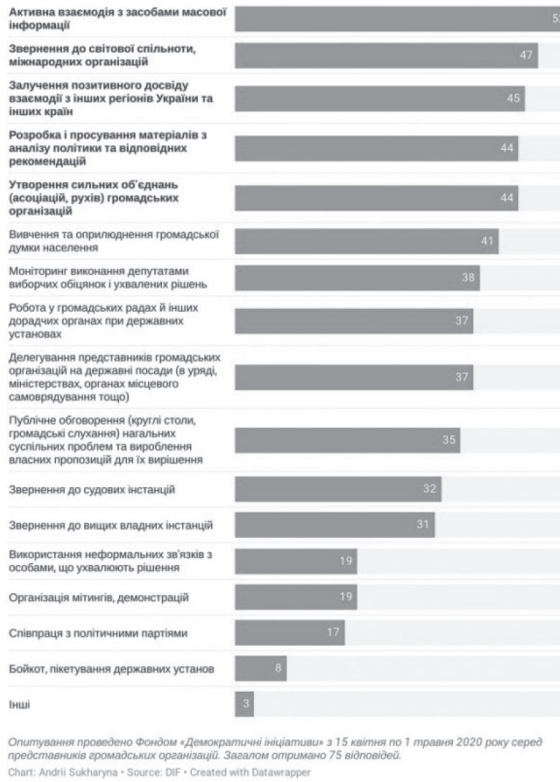

Основні проблеми взаємовідносин громадських організацій з владою (згадок)

За версією організацій громадянського суспільства

Небажання влади йти на співпрацю,

упереджене ставлення до НУО

Пасивність та байдужість населення

Непрозорість влади, відсутність інформацій про ї рішення

Корупція в органах влади

Активний наступ влади проти незалежних го та громадських активістів

Неавторитетність НуО у суспільств

Конфпікти між самими НУО, нездатність формувати та обстоювати спільну позицін

Непрофесійність НУО, незнання чинного законодавства

Упередженість нуо, нездатність до діалогу з владою та компромісів

Відсутність правових механізмів контролю громадськості за владою

Невміння НУО працювати зі змі формувати громадську думку

Інші

Таких проблем сьогодні не існуе

Важко сказати

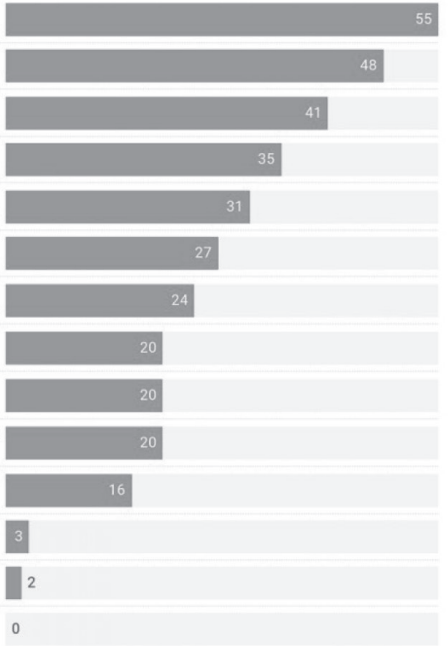

Опитування проведено фондом «Демократичні ініціативи» 15 квітня по 1 травня 2020 року серед nредставників громадських ораанізацій. Зазалом отримано 75 відповідё.

Chart: Andrii Sukharyna . Source: DIF. Created with Datawrapper

Показники рівня активності та впливу на владу

\section{Результати опитування щодо наявності інформації про діяльність НУО у студентів}

\begin{tabular}{|c|c|c|c|c|c|}
\hline Питання & \multicolumn{4}{|c|}{ Відповіді } & Примітки \\
\hline 1 & \multicolumn{4}{|c|}{2} & 3 \\
\hline $\begin{array}{l}\text { 1. Вкажіть свою вікову } \\
\text { категорію. }\end{array}$ & $\begin{array}{l}18-25 \\
88 \text { осіб }\end{array}$ & $\begin{array}{l}26-35 \\
24 \text { особи }\end{array}$ & $\begin{array}{l}36-50 \\
7 \text { осіб }\end{array}$ & $\begin{array}{l}3 \text { З } 50 \\
4 \text { особи }\end{array}$ & $\begin{array}{l}\text { До опитування були } \\
\text { залучені студенти ден- } \\
\text { ної та заочної форм } \\
\text { навчання }\end{array}$ \\
\hline $\begin{array}{l}\text { 2. Чи маєте Ви ін- } \\
\text { формацію про наявні } \\
\text { неурядові громадські } \\
\text { організації у Вашо- } \\
\text { му місті? Якщо так, то } \\
\text { яких? }\end{array}$ & \multicolumn{2}{|c|}{$\begin{array}{l}\text { Так-47 } \\
\text { "Вогонь відро- } \\
\text { дження" (4 відпо- } \\
\text { віді); “Громадська } \\
\text { думка"; “Демокра- } \\
\text { тичний молодіж- } \\
\text { ний альянс"; “Сво- } \\
\text { бода"; "Червоний } \\
\text { хрест”; "Спорт для } \\
\text { всіх"; “Автоном- } \\
\text { ні націоналісти”; } \\
\text { "Озеленення на- } \\
\text { шого міста" }\end{array}$} & \multicolumn{2}{|l|}{$\mathrm{Hi}-72$} & $\begin{array}{l}3 \text { тих, що відповіли } \\
\text { “так”, деякі респонден- } \\
\text { ти не змогли пригада- } \\
\text { ти назви організацій, } \\
\text { деякі вказували назви } \\
\text { Міністерств України, } \\
\text { громадських центрів, } \\
\text { асоціації з футболу, } \\
\text { політичних організа- } \\
\text { цій, управління праці } \\
\text { та соціального захисту } \\
\text { населення тощо }\end{array}$ \\
\hline $\begin{array}{l}\text { 3. Чи маєте Ви будь- } \\
\text { яку інформацію про } \\
\text { діяльність неурядових }\end{array}$ & \multicolumn{2}{|l|}{ Так -47} & \multicolumn{2}{|l|}{$\mathrm{Hi}-72$} & \\
\hline
\end{tabular}


Продовження табл.

\begin{tabular}{|c|c|c|c|}
\hline 1 & \multicolumn{2}{|c|}{2} & 3 \\
\hline $\begin{array}{l}\text { громадських організа- } \\
\text { цій у місті? }\end{array}$ & & & \\
\hline $\begin{array}{l}\text { 4. Чи були Ви коли-не- } \\
\text { будь членом будь-якої } \\
\text { неурядової громад- } \\
\text { ської організації? }\end{array}$ & Так -9 & $\mathrm{Hi}-114$ & $\begin{array}{l}3 \text { них: } \\
\text { віком до } 25 \text { років - } 7 \\
\text { осіб; від } 26 \text { до } 35- \\
1 \text { особа; від } 36 \text { до } 50 \text { - } \\
1 \text { особа }\end{array}$ \\
\hline $\begin{array}{l}\text { 6. Чи хотіли б Ви ста- } \\
\text { ти членом неурядової } \\
\text { громадської організа- } \\
\text { ції? }\end{array}$ & Так - 33 & $\mathrm{Hi}-90$ & $\begin{array}{l}\text { Деякі з респондентів } \\
\text { нічого не знають про } \\
\text { діяльність неурядових } \\
\text { громадських організа- } \\
\text { цій, проте хочуть бути } \\
\text { членами таких органі- } \\
\text { зацій }\end{array}$ \\
\hline $\begin{array}{l}\text { 7. Якщо так, у якій сфе- } \\
\text { рі діяльності (правоза- } \\
\text { хисні, культурні, освіт- } \\
\text { ні, творчі, спортивні, } \\
\text { екологічні)? }\end{array}$ & & & $\begin{array}{l}\text { У порядку зменшен- } \\
\text { ня: спортивні, творчі, } \\
\text { освітні, правозахисні, } \\
\text { екологічні }\end{array}$ \\
\hline $\begin{array}{l}\text { 8. Чи є Ви клієнтом не- } \\
\text { урядової громадської } \\
\text { організації? }\end{array}$ & Так -9 & $\mathrm{Hi}-114$ & \\
\hline $\begin{array}{l}\text { 9. Чи довіряєте Ви } \\
\text { неурядовим громад- } \\
\text { ським організаціям? }\end{array}$ & Так -42 & $\mathrm{Hi}-81$ & \\
\hline $\begin{array}{l}\text { 10. Чи задоволені Ви } \\
\text { діяльністю неурядових } \\
\text { громадських організа- } \\
\text { цій? }\end{array}$ & Так - 46 & $\mathrm{Hi}-87$ & \\
\hline $\begin{array}{l}\text { 11. Як Ви думаєте, чи } \\
\text { впливають неурядові } \\
\text { громадські організації } \\
\text { на формування пози- } \\
\text { тивних взаємовідно- } \\
\text { син між органами вла- } \\
\text { ди та громадянами? }\end{array}$ & Так - 82 & $\mathrm{Hi}-41$ & $\begin{array}{l}\text { Ті респонденти, що не } \\
\text { мають інформації про } \\
\text { діяльність неурядових } \\
\text { громадських організа- } \\
\text { цій, вважають, що вза- } \\
\text { ємини між органами } \\
\text { влади та громадянами } \\
\text { формуються у пози- } \\
\text { тивному напрямі }\end{array}$ \\
\hline $\begin{array}{l}\text { 12. Як Ви думаєте, чиї } \\
\text { інтереси представля- } \\
\text { ють неурядові громад- } \\
\text { ські організації? }\end{array}$ & Громадян - 76 & $\begin{array}{l}\text { Окремих осіб - } \\
45\end{array}$ & $\begin{array}{l}2 \text { особи вважають, що } \\
\text { і тих й інших }\end{array}$ \\
\hline $\begin{array}{l}\text { 13. Чи чули Ви інфор- } \\
\text { мацію від представ- } \\
\text { ників будь-якої не- } \\
\text { урядової громадської } \\
\text { організації стосовно }\end{array}$ & Так -41 & $\mathrm{Hi}-82$ & $\begin{array}{l}\text { Хоча "так" отрима- } \\
\text { но } 42 \text { відповіді, однак } \\
\text { жоден респондент не } \\
\text { назвав таку організа- } \\
\text { цію }\end{array}$ \\
\hline
\end{tabular}


Закінчення табл.

\begin{tabular}{|c|c|c|c|}
\hline 1 & \multicolumn{2}{|l|}{2} & 3 \\
\hline $\begin{array}{l}\text { ефективності іïробо- } \\
\text { ти? Якщо так, то якої? }\end{array}$ & & & \\
\hline $\begin{array}{l}\text { 14. Як Ви вважаєте, чо- } \\
\text { го не вистачає органам } \\
\text { місцевого самовряду- } \\
\text { вання для здійснення } \\
\text { ефективної діяльності } \\
\text { у сфері співпраці з гро- } \\
\text { мадянами? }\end{array}$ & $\begin{array}{l}\text { Сорому; ініціати- } \\
\text { ви; щедрості; ви- } \\
\text { конання обіцянок; } \\
\text { більшого спілку- } \\
\text { ваннязгромадяна- } \\
\text { ми і створення для } \\
\text { цього відповідних } \\
\text { відділів; доброчес- } \\
\text { ності; сміливості; } \\
\text { справедливості; } \\
\text { чесності; прозоро- } \\
\text { сті; фінансового } \\
\text { забезпечення; ро- } \\
\text { зумних рішень; по- } \\
\text { рядності; розумін- } \\
\text { ня громадян; ба- } \\
\text { жання; жадібність } \\
\text { до грошей; розу- } \\
\text { му; мети; мотиву }\end{array}$ & & \\
\hline $\begin{array}{l}\text { 15. Чи хотіли б Ви стати } \\
\text { громадським лідером? }\end{array}$ & Так -27 & $\mathrm{Hi}-96$ & $\begin{array}{l}\text { Одним з факторів є не- } \\
\text { бажання брати на себе } \\
\text { повноваження і відпо- } \\
\text { відальність }\end{array}$ \\
\hline $\begin{array}{l}\text { 16. Чим Вас можна мо- } \\
\text { тивувати до прийняття } \\
\text { активної діяльності у } \\
\text { житті міста? }\end{array}$ & $\begin{array}{l}\text { Цінуванням про- } \\
\text { веденої роботи, } \\
\text { матеріальним за- } \\
\text { охоченням - } 7 \text { від- } \\
\text { повідей; повнова- } \\
\text { женнями, нічим - } 6 \\
\text { відповідей; куль- } \\
\text { турними заходами, } \\
\text { порядком, покра- } \\
\text { щенням життя й } \\
\text { суспільного ладу, } \\
\text { обґрунтованим } \\
\text { планом дій - } 2 \text { від- } \\
\text { повіді; владою, } \\
\text { пропозиціями, ре- } \\
\text { альними діями }\end{array}$ & & $\begin{array}{l}21 \text { особа зазначає, } \\
\text { що мотивувати можна, } \\
\text { але чим - не вказують }\end{array}$ \\
\hline
\end{tabular}

* Всього опитано 123 особи.

Джерело: проведено та складено автором.

Зазначимо, що респонденти не відрізняють громадські організації від інших об'єднань та організацій і структур державного управління.
Отже, НУО, зі свого боку, мають краще інформувати про наявний кадровий, професійний та ресурсний потенціал, визначити заходи спіль- 
них дій щодо організаційно-правового забезпечення надання якісних послуг, які мають гуртуватись на принципах відкритості та взаємодії, запровадити систему моніторингових оцінок якості своїх послуг та доводити таку інформацію до громадськості. 3 огляду на це, однією 3 головних перешкод, яка суттєво гальмує розвиток вітчизняного неурядового сектору на сучасному етапі, залишається дефіцит інституціоналізації громадянської активності населення. Як наслідок - домінуючою формою впливу громадян на процеси державного управління залишається колективна мітинговість, а не публічно-партнерська взаємодія при вирішенні соціальних проблем [6].

Висновки. Не зменшуючи важливості усіх чинників розвитку взаємодії, що досліджується, окремо слід виділити забезпечення прозорості та відкритості інститутів громадянського суспільства. Ціллю діалогу в системі публічного управління можна вважати створення дієвого механізму взаємодії у напрямі вирішення складних суспільних проблем, в основі якого лежить взаєморозуміння та партнерство. Основна мета такої взаємодії полягає в зміцненні механізмів громадянського партнерства, в своєчасному виявленні та усуненні детермінант, які можуть призвести до гострих конфліктів і дезорганізації в житті суспільства.

\section{СПИСОК ВИКОРИСТАНИХ ДЖЕРЕЛ}

1. Політологія: лекційний курс і практикум : навч. посіб. / Т. В. Гончарук, M. I. Гурик, I. С. Дмитрієв. Тернопіль : АСТОН, 2009. 376 с.
2. Усаченко Л. М. Співпраця органів державної влади 3 інститутами громадянського суспільства // Актуальні проблеми державного управління. 2009. № 1. С. 73-81. URL: http://nbuv.gov.ua/UJRN/ apdy_2009_1_11

3. Стан та динаміка розвитку неурядових організацій України 20022006 рр.: Аналіт. звіт Творч. центру "Каунтерпарт". К., 2006. 103 с.

4. Михайловсъка О. В. Деякі аспекти комунікативної взаємодії органів місцевого самоврядування та громадськості // Наук. вісн. Полісся. Чернігів: ЧНТУ, 2016. № 1 (5). 136 с. Режим доступу : URL: http://nvp.stu.cn.ua/uk/component/ $\mathrm{k} 2 /$ item/472-mihaylovska-o-vdeyaki-aspekti-komunikativnoyivzaemodiyi-organiv-mistsevogosamovryaduvannya-ta-gromadskosti. html

5. Рівень громадської активності населення в умовах карантину оцінили як середній. Центр “Громадський простір": веб-сайт URL: https:// ww w.prostir.ua/? news=rivenhromadskoji-aktyvnosti-v-ukrajiniv-umovah-karantynu-otsinyly-yakserednij

6. Якубовський О. Державна влада i громадянське суспільство: система взаємодії : монографія / О. Якубовський, Т. Бутирська. О.: ОРІДУ НАДУ, 2004. 196 с.

\section{REFERENCES}

1. Honcharuk T. V., Huryk M. I., Dmytriiev I. S. (2009). Politolohiia [Politology]. Ternopil: ASTON [in Ukrainian].

2. Usachenko L. M. (2009). Spivpratsia orhaniv derzhavnoi vlady z instytutamy hromadianskoho suspilstva [Cooperation of public authorities with civil society institutions]. Aktualni problemy derzhavnoho upravlinnia - Actual 
problems of public administration, 1, 73-81. Retrieved from http://nbuv. gov.ua/UJRN/apdy_2009_1_11 [in Ukrainian].

3. Stan ta dynamika rozoytku neuriadovykh orhanizatsii Ukrainy 2002$2006 \mathrm{rr}$. [Status and dynamics of development of non-governmental organizations in Ukraine in 2002-2006]. (2006). Kyiv [in Ukrainian].

4. Mykhailovska O. V. (2016). Deiaki aspekty komunikatyvnoi vzaiemodii orhaniv mistsevoho samovriaduvannia ta hromadskosti [Some aspects of communicative interaction between local authorities and the public]. Naukovyi visnyk Polissia - Scientific Bulletin of Polissia, 1(5), 56-63. Retrieved from http:// nvp.stu.cn.ua/uk/component/k2/ item/472-mihaylovska-o-v-deyaki- aspekti-komunikativnoyi-vzaemodiyi-organiv-mistsevogo-samovryaduvannya-ta-gromadskosti.html [in Ukrainian].

5. Riven hromadskoi aktyvnosti naselennia v umovakh karantynu otsinyly yak serednii. Tsentr "Hromadskyi prostir" [The level of public activity of the population in quarantine was assessed as average]. (2020). wrow.prostir.ua. Retrieved from https://www. prostir.ua/?news=riven-hromadskoji-aktyvnosti-v-ukrajini-v-umovahkarantynu-otsinyly-yak-serednij [in Ukrainian].

6. Yakubovskyi O., Butyrska T. (2004). Derzhavna vlada i hromadianske suspilstvo: systema vzaiemodii [State power and civil society: system of interaction]. Odesa: ORIDU NADU [in Ukrainian]. 